(RESEARCH ARTICLE)

\title{
Design and optimization of clotrimazole emulgel by using various polymers
}

\author{
AVS MadhuLatha *, N Sojana, N Mounika, G Priyanka, A Venkatesh and JN Suresh Kumar \\ Department of Pharmaceutics, Narasaraopeta Institute of Pharmaceutical Sciences,Narasaraopeta, Andhra Pradesh, \\ India.
}

Publication history: Received on 27 July 2020; revised on 12 August 2020; accepted on 14 August 2020

Article DOI: https://doi.org/10.30574/wjarr.2020.7.2.0281

\begin{abstract}
Emulgel is one of the recent technologies in Novel Drug Delivery system (NDDS) used for dual controlled release of emulsion and gel for topical use. The stability of emulsion is increased, when it is incorporated into gel. Clotrimazole is a broad spectrum anti - fungal agent, also a hydrophobic drug. It is difficult to formulate as topical delivery. So emulgel is one of the best approaches to incorporate hydrophobic drugs. The purpose of the present study was to develop and optimized the Clotrimazole emulgel using polymers like Carbopol 934 and HPMC K4M at different concentrations. The Preformulation studies were conducted by using Fourier Transform Infrared (FTIR) studies, the prepared emulgels were evaluated in terms of physical appearance, measurement of $\mathrm{pH}$, viscosity, spreadability, drug content and in vitro diffusion studies. In vitro drug release studies were performed up to 8hrs. Among all formulations F6 shows better releasing property. So F6 was proved as the best formulation among all. F6 containing HPMC K4M polymer in low concentration showed better releasing property when compared to formulations containing Carbopol 934. So it was suggested that the Clotrimazole emulgel have potential advantages when compared to other topical drug delivery systems for incorporating hydrophobic drugs and posses better activity and stability.
\end{abstract}

Keywords:Topical drug delivery; Emulgel; Clotrimazole; Carbopol 934; HPMC K4M; In vitro Diffusion Studies.

\section{Introduction}

Topical formulations apply a wide spectrum of preparations both cosmetic and dermatological, to healthy or diseased skin [1], [2]. These formulations range in consistency from solid through semisolid to liquids. When gels and emulsions are used in a combined form, the dosage forms are referred to Emulgel [3], [4]. As the name suggests they are the combination of emulsion/microemulsion and gel. Novel polymers with complex functions as emulsifiers and thickeners have been widely used due to their gelling capacity which allows the formulation of stable emulsion by decreasing surface and interfacial tension and also by increasing the viscosity of the aqueous phase. Oil/water and water/oil emulsions are used as vehicles to deliver various drugs to the skin [5]. Emulgels are gaining importance due to many reasons; they have better application property in comparison to classical formulation as creams and ointment, they have faster and more complete release of the drug from the vehicle to the skin, also they are convenient to apply on hairy skin due to the absence of greasiness and lack of residue upon application. They permit the incorporation of both aqueous and oleaginous ingredients, so hydrophobic or poorly water soluble drugs as antifungal agents are easily incorporated in such type of vehicles through the proper choice of the oily phase [6]. Clotrimazole is an antifungal agent which inhibits the growth of pathogenic dermatophytes. It shares with Econazole, miconazole, first choice status for topical treatment of tineapedis, tineacruris and tineacorporis due to Candida albicans. It is effective for topical treatment of vulvovaginal and or pharyngeal candidacies [7], [8], [9] for skin care and the topical treatment of dermatological diseases, a wide choice of vehicles including solid, semisolids and liquid preparations is available to physicians and patients Emulgel or gellified emulsion is stable one and better vehicle for hydrophobic or water insoluble drugs as Clotrimazole. Also emulgels have a high patient acceptability since they possess the advantages of both emulsions and gels. Therefore, they have been recently used as vehicles to deliver various drugs to the skin.

\footnotetext{
* Corresponding author: AVS Madhu Latha
} 
Topical drug delivery can be defined as the application of a drug directly to the skin to treat skin diseases or disorders with the intent of containing the pharmacological effect. Topical drug delivery is mainly used to remove the first pass metabolism and to get onset of action [10], [11], [12].The study of structure and physiology of skin is important for designing topical dosage form, because the topical preparations are meant to apply to the skin.

The skin contains four different layers [13] like;

- Non-viable epidermis

- Viable epidermis

- Dermis

- Subcutaneous connective tissue.

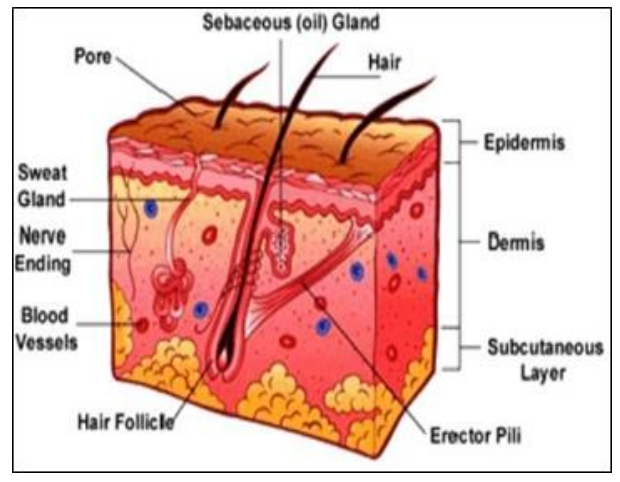

Figure 1 Anatomy of Skin

Over the last decades the treatment of illness has been accomplished by oral, sublingual, rectal, parenteral and topically. Topical drug delivery can be defined as the application of a drug containing formulation to the skin to treat cutaneous disease or disorder directly. This delivery is through by ophthalmic, rectal, and vaginal and skin [14], [15], [16]. The topical drug delivery is used for both dermatological and cosmetic purpose. The main advantage of topical drug delivery system is to bypass first pass metabolism. One of the formulations in the topical drug delivery system is the Emulgels. They also have a high ability to penetrate the skin. Emulgel for dermatological use has several favorable properties like thixotropic, greaseless, easily spreadable, easily removable, emollient, non-staining, water soluble longer shelf life, bio friendly, transparent and pleasing appearance. Hence the present works mainly concentrate on the better incorporation of drugs though the skin, at the same time incorporation of hydrophobic drugs also.

\section{Material and methods}

Clotrimazole was purchased from AlapatiPharma (Ongole, India), Carbopol 934, HPMC K4M, from Indian research products (Chennai, India).All other chemicals and reagents used were of laboratory or analytical grade.

\subsection{Methodology}

Preformulation studies Preformulation testing is an investigation of physical and chemical properties of a drug substance alone and when combined with excipients. It is the first step in the rational development of dosage forms [17, 18]

\subsubsection{Analytical tests for API (Active pharmaceutical ingredient)}

- Solubility analysis: Preformulation solubility analysis was done, which include the selection of suitable solvents to dissolve the drug and also excipients.

- Melting point deter

- mination: It was done for the drug sample, as it is a first indication of purity of the sample.

\subsubsection{Drug Excipient compatibility studies}

Fourier Transformer Infrared Spectroscopy (FTIR) the possible incompatibilities between the active drug substance and different excipients form an important part of the Preformulation stage during the development of a dosage form. The use of FTIR technique allows pointing out the implication of the different functional groups of drug and excipients 
by analyzing the significant changes in the shape and position of the absorbance bands. In this method individual samples as well as the mixture of drug and excipients were ground mixed thoroughly with potassium bromide $(1: 100)$ for 3-5 min in a mortar and compressed into disc by applying pressure of 5 tons for $5 \mathrm{~min}$ in hydraulic press. The pellet was kept in the sample holder and scanned from 4000 to $400 \mathrm{~cm}^{-1}$ in FTIR spectrophotometer. Then the characteristics peaks were obtained of all sample as well as mixtures [19].

\subsection{Formulation Development}

\subsubsection{Standard curve of clotrimazole}

Preparation of pH 7.4 Phosphate Buffer Solution

$50 \mathrm{ml}$ of $0.2 \mathrm{M}$ Potassium dihydrogen phosphate mixed with $39.1 \mathrm{ml}$ of $0.2 \mathrm{M}$ sodium hydroxide which gives $200 \mathrm{ml}$ of pH 7.4 Phosphate Buffer Solution.

\section{Preparation of Standard Solution of Clotrimazole}

$100 \mathrm{mg}$ of Clotrimazole was accurately weighed and transferred in to $100 \mathrm{ml}$ volumetric flask. $50 \mathrm{ml}$ of methanol was added to it. Then the solution was makeup to the final volume with $\mathrm{pH} 7.4$ phosphate buffer solution to give a final concentration of $1 \mathrm{mg} / \mathrm{ml}$.

Preparation of Working Standard Solution of Clotrimazole

From the stock solution, different aliquots of $0.1,0.15,0.2,0.25,0.3,0.35 \mathrm{ml}$ were taken and dilute up to $10 \mathrm{ml}$ with buffer to give concentrations of $5 \mu \mathrm{g} / \mathrm{ml} 10 \mu \mathrm{g} / \mathrm{ml}, 15 \mu \mathrm{g} / \mathrm{ml}, 20 \mu \mathrm{g} / \mathrm{ml}, 25 \mu \mathrm{g} / \mathrm{ml}, 30 \mu \mathrm{g} / \mathrm{ml}, 35 \mu \mathrm{g} / \mathrm{ml}$ of Clotrimazole respectively. The absorbance of each solution was measured by UV Visible Spectrophotometer at $262 \mathrm{~nm}$ using phosphate buffer solution pH 7.4 as blank. The graph of concentration versus absorbance was plotted.

\subsubsection{Preparation of Emulsion [20]}

Preparation of aqueous phase: The aqueous phase of the Emulsion was prepared by dissolving Tween 80 in purified water. Preparation of Oil phase: Methyl Paraben and Propyl Paraben were dissolved in propylene glycol where as drug was dissolved in ethanol and both solutions were mixed with the aqueous phase. Both the oily and aqueous phases were separately heated to $75^{\circ} \mathrm{C}$. Then the oil phase was added to the aqueous phase with continuous stirring until cooled to room temperature.

\subsubsection{Preparation of Gel Phase}

The gel bases were prepared by dispersing different concentrations of polymers in distilled water separately with constant stirring at a moderate speed using mechanical shaker. The $\mathrm{pH}$ of all formulations was adjusted to 6-6.5 using Triethanolamine (TEA).

\subsubsection{Preparation of Emulgel}

The obtained emulsion was mixed with gel with gentle stirring to obtain the emulgel.

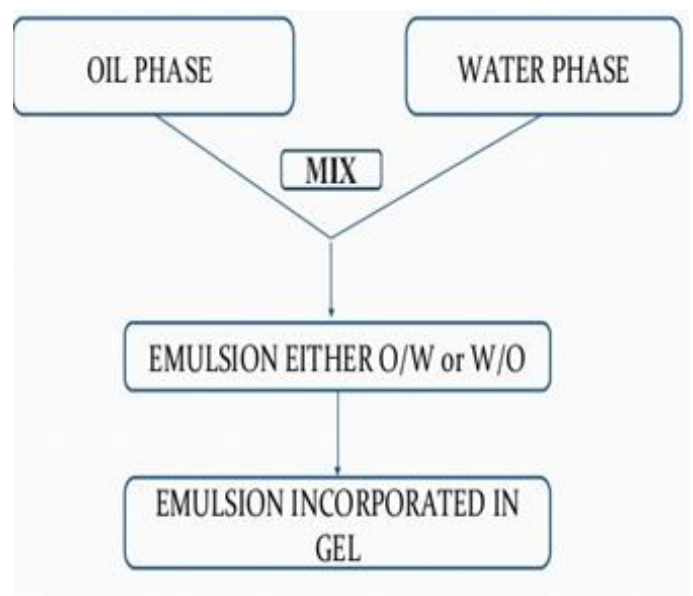




\subsection{Evaluation Studies for Emulgel}

\subsubsection{Physical Examination and pH Determination}

The prepared Clotrimazole were inspected visually for their color, homogeneity, consistency and $\mathrm{Ph}$ values of $1 \%$ aqueous solutions of the prepared emulgels were measured by a $\mathrm{pH}$ meter. Experiments were carried out in triplicates.

\subsubsection{Spreadability test}

A sample of $0.5 \mathrm{~g}$ of each formula was pressed between two slides (divided into squares of $5 \mathrm{~mm}$ sides) and left for about 5 minutes where no more spreading was expected. Diameters of spreaded circles were measured in $\mathrm{cm}$ and were taken as comparative values for Spreadability. The results obtained are average of three determinations.

\subsubsection{Rheological Studies}

The viscosity of the formulated batches was determined using a cone and plate viscometer with spindle. The assembly was connected to a thermostatically controlled circulating water bath maintained at $25^{\circ} \mathrm{C}$. The formulation whose viscosity was to be determined was added to a beaker covered with thermostatic jacket. Spindle was allowed to move freely into the emulgel and the reading was noted.

\subsubsection{Drug content determination}

The drug content of Clotrimazoleemulgel was measured by dissolving a known weight of the emulgel formulation (one gram) in $100 \mathrm{ml}$ methanol, appropriate dilutions were made and the resulting solution was then filtering using Millipore filter. Absorbance was measured at $262 \mathrm{~nm}$ using UV- spectrophotometer. Dug content was calculated using the slope and the intercept obtained by linear regression analysis of standard calibration curve. Experiments were carried out in triplicates.

\subsubsection{In vitro release studies}

The in vitro drug release studies were carried out using a modified Franz diffusion (FD) cell. The formulation was applied on dialysis membrane which was placed between donor and receptor compartment of the FD cell. Phosphate buffer $\mathrm{pH} 7.4$ was used as a dissolution media. The temperature of the cell was maintained at $37^{\circ} \mathrm{C}$ by circulating water jacket. This whole assembly was kept on a magnetic stirrer and the solution was stirred continuously using a magnetic bead. A similar blank set was run simultaneously as a control. Sample $(5 \mathrm{ml})$ was withdrawn at suitable time intervals and replaced with equal amounts of fresh dissolution media. Samples were analyzed spectrophotometrically at $262 \mathrm{~nm}$ and the cumulative \% drug release was calculated. The difference between the readings of drug release and control was used as the actual reading in each case.

\begin{tabular}{|l|l|l|l|l|l|l|l|l|l|}
\hline S. No & Materials & $\mathbf{F}_{\mathbf{1}}$ & $\mathbf{F}_{\mathbf{2}}$ & $\mathbf{F}_{\mathbf{3}}$ & $\mathbf{F}_{\mathbf{4}}$ & $\mathbf{F}_{\mathbf{5}}$ & $\mathbf{F}_{\mathbf{6}}$ & $\mathbf{F}_{\mathbf{7}}$ & $\mathbf{F}_{\mathbf{8}}$ \\
\hline 1 & Clotrimazole & $1 \mathrm{gm}$ & $1 \mathrm{gm}$ & $1 \mathrm{gm}$ & $1 \mathrm{gm}$ & $1 \mathrm{gm}$ & $1 \mathrm{gm}$ & $1 \mathrm{gm}$ & $1 \mathrm{gm}$ \\
\hline 2 & Carbopol 934 & $1 \mathrm{gm}$ & - & $1 \mathrm{gm}$ & - & $1 \mathrm{gm}$ & - & $1 \mathrm{gm}$ & - \\
\hline 3 & H P M C K4M & - & $2.5 \mathrm{gm}$ & - & $2.5 \mathrm{gm}$ & - & $2.5 \mathrm{gm}$ & - & $2.5 \mathrm{gm}$ \\
\hline 4 & Liquid Paraffin & $5 \mathrm{ml}$ & $5 \mathrm{ml}$ & $7.5 \mathrm{ml}$ & $7.5 \mathrm{ml}$ & $5 \mathrm{ml}$ & $5 \mathrm{ml}$ & $7.5 \mathrm{ml}$ & $7.5 \mathrm{ml}$ \\
\hline 5 & Tween 80 & $0.6 \mathrm{ml}$ & $0.6 \mathrm{ml}$ & $0.6 \mathrm{ml}$ & $0.6 \mathrm{ml}$ & $1 \mathrm{ml}$ & $1 \mathrm{ml}$ & $1 \mathrm{ml}$ & $1 \mathrm{ml}$ \\
\hline 6 & Span 80 & $0.9 \mathrm{ml}$ & $0.9 \mathrm{ml}$ & $0.9 \mathrm{ml}$ & $0.9 \mathrm{ml}$ & $1.5 \mathrm{ml}$ & $1.5 \mathrm{ml}$ & $1.5 \mathrm{ml}$ & $1.5 \mathrm{ml}$ \\
\hline 7 & Propylene Glycol & $5 \mathrm{ml}$ & $5 \mathrm{ml}$ & $5 \mathrm{ml}$ & $5 \mathrm{ml}$ & $5 \mathrm{ml}$ & $5 \mathrm{ml}$ & $5 \mathrm{ml}$ & $5 \mathrm{ml}$ \\
\hline 8 & Methyl Paraben & $0.03 \mathrm{mg}$ & $0.03 \mathrm{mg}$ & $0.03 \mathrm{mg}$ & $0.03 \mathrm{mg}$ & $0.03 \mathrm{mg}$ & $0.03 \mathrm{mg}$ & $0.03 \mathrm{mg}$ & $0.03 \mathrm{mg}$ \\
\hline 9 & Ethanol & $2.5 \mathrm{ml}$ & $2.5 \mathrm{ml}$ & $2.5 \mathrm{ml}$ & $2.5 \mathrm{ml}$ & $2.5 \mathrm{ml}$ & $2.5 \mathrm{ml}$ & $2.5 \mathrm{ml}$ & $2.5 \mathrm{ml}$ \\
\hline 10 & Benzoic acid & $0.01 \mathrm{gm}$ & $0.01 \mathrm{gm}$ & $0.01 \mathrm{gm}$ & $0.01 \mathrm{gm}$ & $0.01 \mathrm{gm}$ & $0.01 \mathrm{gm}$ & $0.01 \mathrm{gm}$ & $0.01 \mathrm{gm}$ \\
\hline 11 & Purified water QS & $100 \mathrm{ml}$ & $100 \mathrm{ml}$ & $100 \mathrm{ml}$ & $100 \mathrm{ml}$ & $100 \mathrm{ml}$ & $100 \mathrm{ml}$ & $100 \mathrm{ml}$ & $100 \mathrm{ml}$ \\
\hline
\end{tabular}




\section{Results}

\subsection{Preformulation Studies of Clotrimazole}

\subsubsection{Drug Excipient Compatibility Studies}

There is no change in major peak of Clotrimazole in the presence of Carbopol 934, HPMC K4M. So the drug and excipients are compatible with each other.

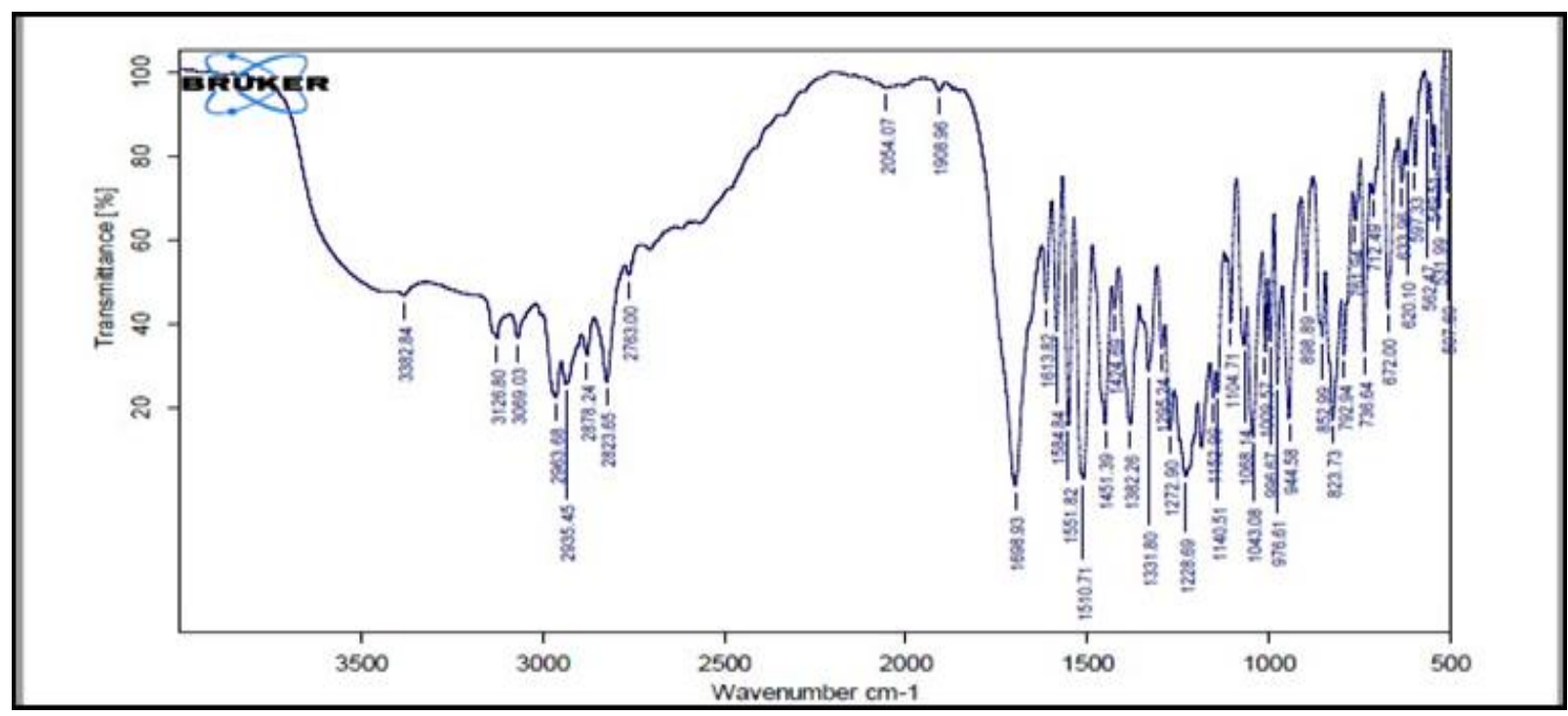

Figure 2 FTIR spectrum of Clotrimazole+ Carbopol 940

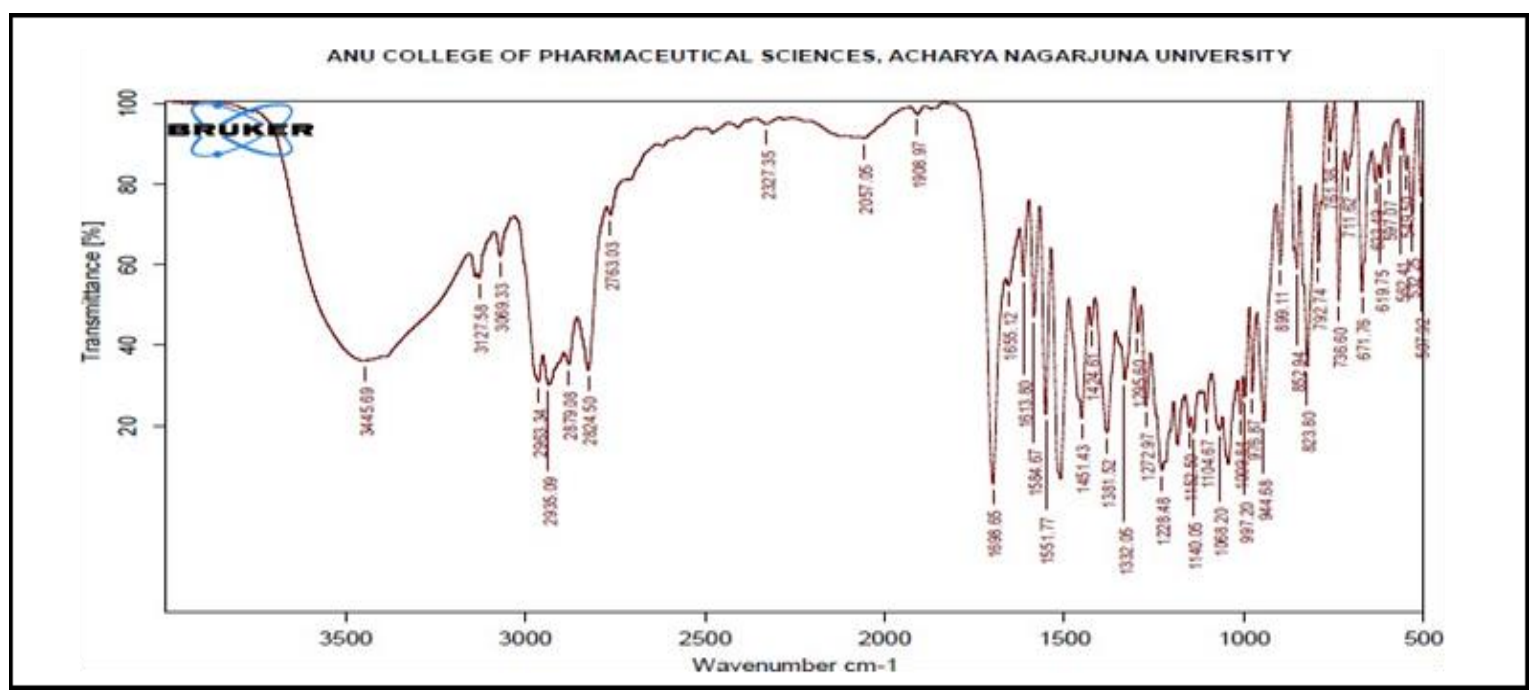

Figure 3 FTIR spectrum of Clotrimazole+HPMCK4M 


\subsubsection{Standard Curve of Clotrimazole}

Table 1 Data for Standard curve of Clotrimazole

\begin{tabular}{|c|c|c|}
\hline S.No & Concentration( $\boldsymbol{\mu g} / \mathbf{m l})$ & $\begin{array}{c}\text { Absorbance at 262nm } \\
\text { ( in pH 7.4 phosphate buffer) }\end{array}$ \\
\hline 1. & 5 & 0.118 \\
\hline 2. & 10 & 0.235 \\
\hline 3. & 15 & 0.348 \\
\hline 4. & 20 & 0.471 \\
\hline 5. & 25 & 0.587 \\
\hline 6. & 30 & 0.696 \\
\hline
\end{tabular}

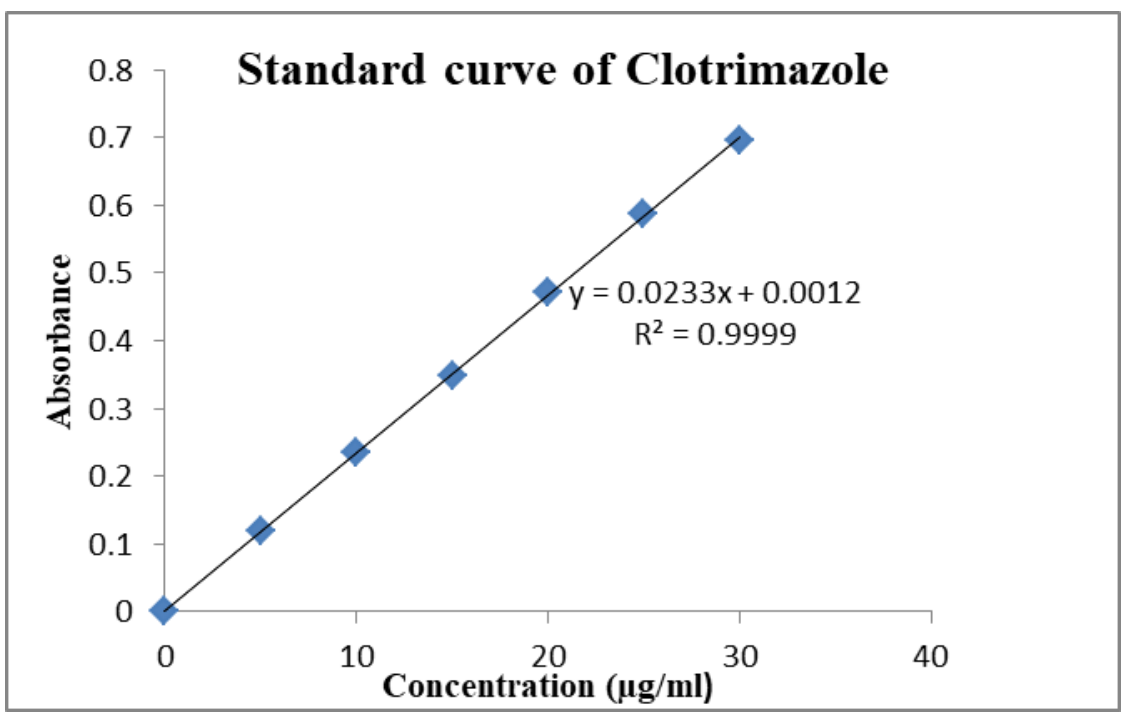

Figure 4 Standard Curve of Clotrimazole

Table 2 Physical examination of emulgel formulations

\begin{tabular}{|c|c|c|c|c|c|c|}
\hline S. No & $\begin{array}{c}\text { Formulation } \\
\text { code }\end{array}$ & Colour & $\begin{array}{c}\text { Phase } \\
\text { separation }\end{array}$ & Grittiness & Homogeneity & Consistency \\
\hline 1 & F1 & White & None & - & Excellent & Excellent \\
\hline 2 & F2 & White & None & - & Excellent & Excellent \\
\hline 3 & F3 & White & None & - & Excellent & Excellent \\
\hline 4 & F4 & White & None & - & Excellent & Excellent \\
\hline 5 & F5 & White & None & - & Excellent & Excellent \\
\hline 6 & F6 & White & None & - & Excellent & Excellent \\
\hline
\end{tabular}


Table $3 \mathrm{pH}$ of emulgel formulations

\begin{tabular}{|c|c|l|}
\hline S.No & Formulation code & pH value \\
\hline 1 & F1 & $6.5 \pm 0.01$ \\
\hline 2 & F2 & $6.3 \pm 0.02$ \\
\hline 3 & F3 & $6.2 \pm 0.1$ \\
\hline 4 & F4 & $6.5 \pm 0.14$ \\
\hline 5 & F5 & $6.4 \pm 0.12$ \\
\hline 6 & F6 & $6.3 \pm 0.14$ \\
\hline
\end{tabular}

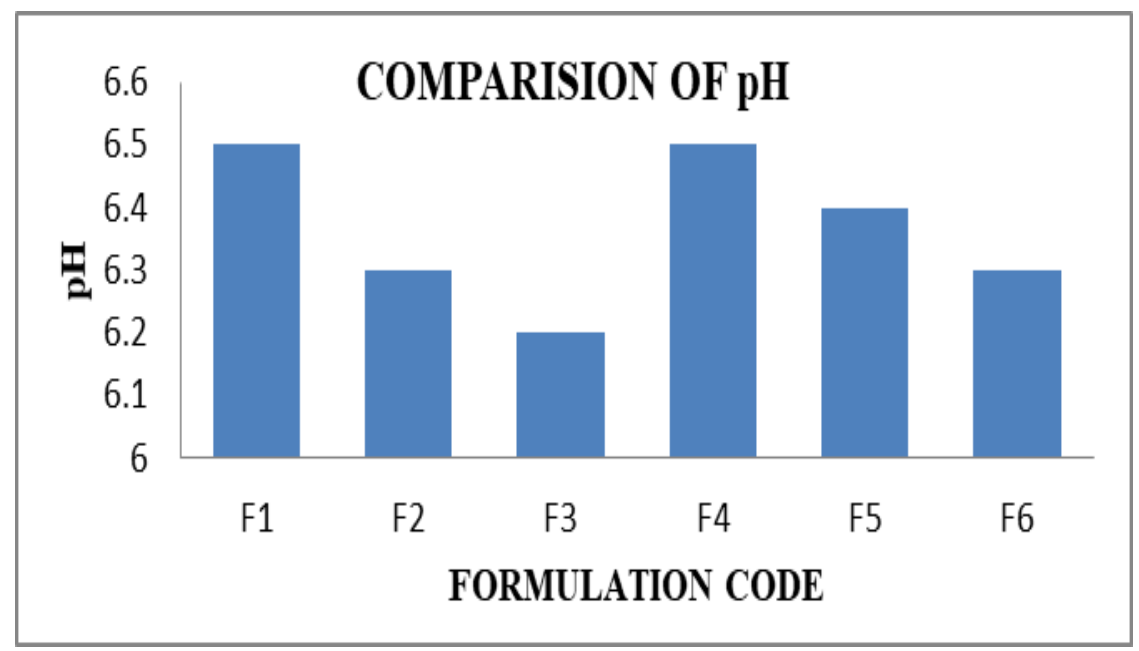

Figure 5 Comparison of $\mathrm{pH}$ in different formulations from $\mathrm{F} 1$ to $\mathrm{F} 6$

Table 4 Spreadability of emulgel formulations

\begin{tabular}{|c|c|c|}
\hline S.No & Formulation code & Spreadability(cm) \\
\hline 1 & F1 & $6.0 \pm 0.1$ \\
\hline 2 & F2 & $5.8 \pm 0.2$ \\
\hline 3 & F3 & $5.7 \pm 0.1$ \\
\hline 4 & F4 & $5.9 \pm 0.05$ \\
\hline 5 & F5 & $5.7 \pm 0.12$ \\
\hline 6 & F6 & $5.5 \pm 0.15$ \\
\hline
\end{tabular}




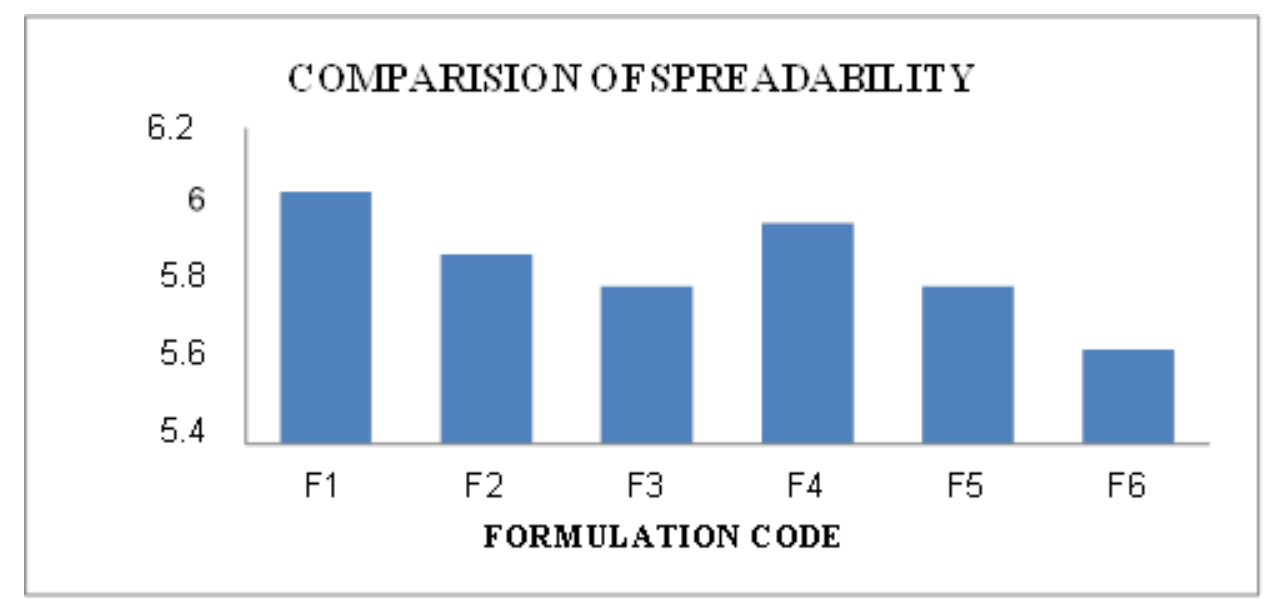

Figure 6 Comparison of Spreadability in different formulations from F1 to F6

Table 5 Viscosity of emulgel formulations

\begin{tabular}{|c|c|c|}
\hline S.No & Formulation code & Viscosity (cp) \\
\hline 1 & F1 & $3337 \pm 0.13$ \\
\hline 2 & F2 & $4528 \pm 0.15$ \\
\hline 3 & F3 & $8129 \pm 0.19$ \\
\hline 4 & F4 & $3529 \pm 0.12$ \\
\hline 5 & F5 & $4693 \pm 0.10$ \\
\hline 6 & F6 & $8232 \pm 0.12$ \\
\hline
\end{tabular}

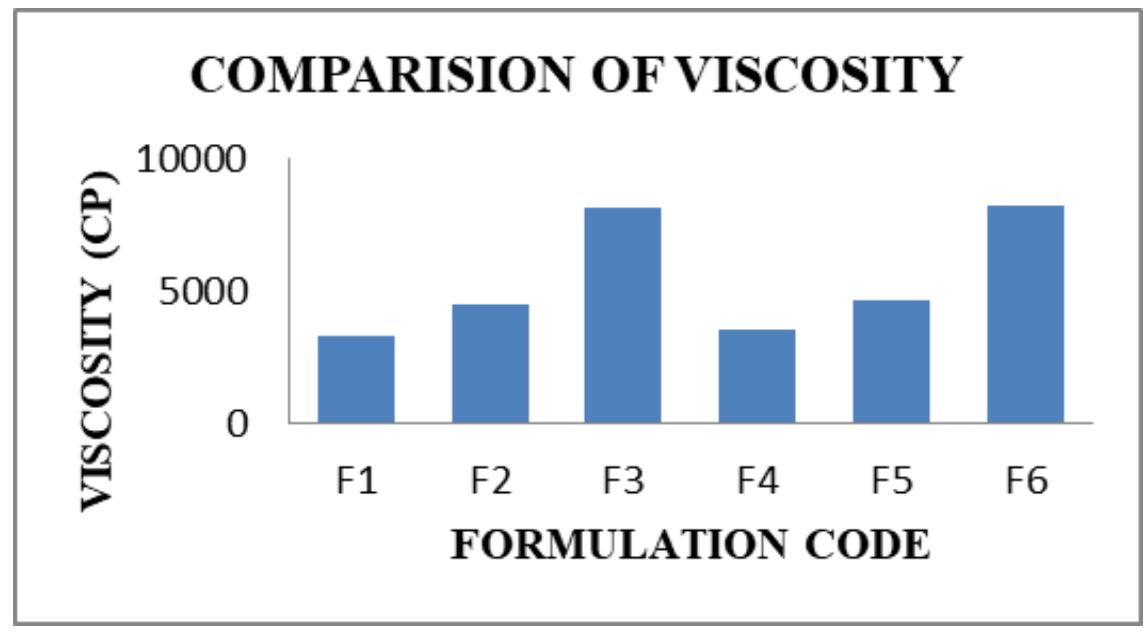

Figure 7 Comparison of Viscosity in different formulations from F1 to F6 
Table 6 Drug content of emulgel formulations

\begin{tabular}{|c|c|c|}
\hline S.No & Formulation code & Drug Content (\%) \\
\hline 1 & F1 & $98.5 \pm 0.01$ \\
\hline 2 & F2 & $97.2 \pm 0.11$ \\
\hline 3 & F3 & $94.22 \pm 0.15$ \\
\hline 4 & F4 & $97.65 \pm 0.12$ \\
\hline 5 & F5 & $96.22 \pm 0.14$ \\
\hline 6 & F6 & $92.17 \pm 0.01$ \\
\hline
\end{tabular}

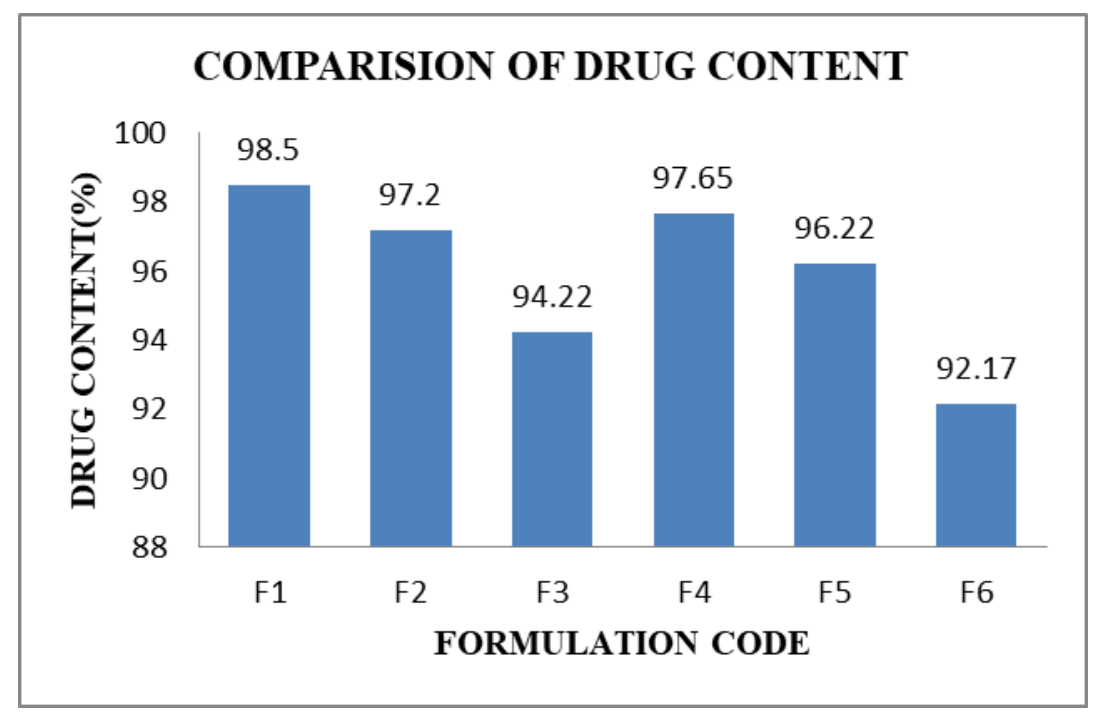

Figure 8 Comparison of Drug Content in different formulations from F1 to F6

Table 7 In vitro drug release of emulgel formulations.

\begin{tabular}{|l|l|l|l|l|}
\hline S.No & Time (hr) & F1 & F2 & F3 \\
\hline 1. & 1 & $5.91 \pm 0.02$ & $7.56 \pm 0.14$ & $6.02 \pm 0.01$ \\
\hline 2. & 2 & $9.25 \pm 0.05$ & $13.95 \pm 0.11$ & $11.87 \pm 0.12$ \\
\hline 3. & 3 & $13.64 \pm 0.05$ & $20.57 \pm 0.14$ & $15.85 \pm 0.14$ \\
\hline 4. & 4 & $18.54 \pm 0.01$ & $25.25 \pm 0.15$ & $20.65 \pm 0.07$ \\
\hline 5. & 5 & $24.29 \pm 0.03$ & $36.65 \pm 0.02$ & $27.87 \pm 0.06$ \\
\hline 6. & 6 & $30.15 \pm 0.05$ & $41.24 \pm 0.17$ & $34.96 \pm 0.05$ \\
\hline 7. & 7 & $35.54 \pm 0.04$ & $45.45 \pm 0.13$ & $39.78 \pm 0.10$ \\
\hline 8. & 8 & $42.12 \pm 0.02$ & $49.65 \pm 0.21$ & $43.05 \pm 0.12$ \\
\hline
\end{tabular}


Table 8 In vitro drug release of emulgel formulations F4 to F6

\begin{tabular}{|l|l|l|l|l|}
\hline S.No & Time (hr) & F4 & F5 & F6 \\
\hline 1. & 1 & $7.92 \pm 0.05$ & $6.86 \pm 0.12$ & $8.05 \pm 0.11$ \\
\hline 2. & 2 & $14.23 \pm 0.12$ & $11.99 \pm 0.11$ & $15.54 \pm 0.01$ \\
\hline 3. & 3 & $22.99 \pm 0.13$ & $18.24 \pm 0.01$ & $24.92 \pm 0.11$ \\
\hline 4. & 4 & $30.93 \pm 0.14$ & $23.22 \pm 0.10$ & $33.25 \pm 0.15$ \\
\hline 5. & 5 & $39.99 \pm 0.02$ & $25.44 \pm 0.12$ & $42.98 \pm 0.02$ \\
\hline 6. & 6 & $47.02 \pm 0.03$ & $31.55 \pm 0.14$ & $51.38 \pm 0.14$ \\
\hline 7 & 7 & $50.85 \pm 0.04$ & $37.99 \pm 0.01$ & $53.11 \pm 0.13$ \\
\hline 8 & 8 & $54.98 \pm 0.02$ & $47.29 \pm 0.23$ & $58.57 \pm 0.11$ \\
\hline
\end{tabular}

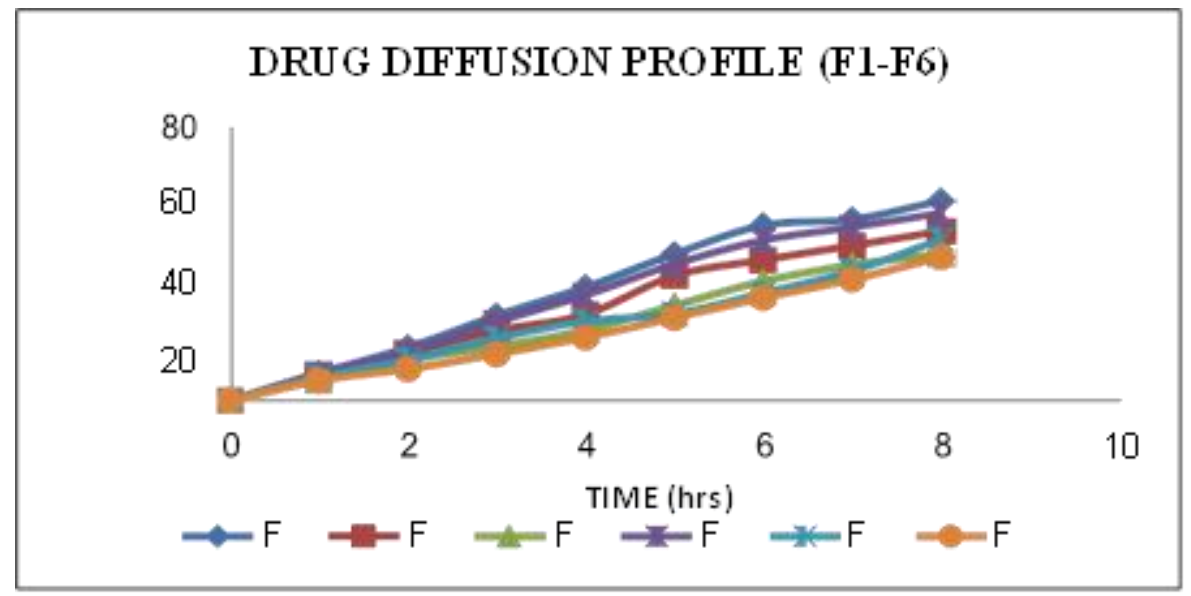

Figure 9 In vitro drug release profile for different formulations from F1 to F6

\section{Discussion}

\subsection{Physical Examination}

The prepared emulgel formulations were white, viscous, creamy preparation with a smooth, homogeneous appearance with good consistency and without any gritty particles.

\subsection{Measurement of $\mathrm{pH}$ The $\mathrm{pH}$ of}

The emulgel formulations was in the range of 6.0 to 6.5 and there was no significant change in $\mathrm{pH}$ values as a function of time for all formulations which are considered acceptable to avoid the risk of irritation upon application to the skin because adult skin $\mathrm{pH}$ is 6.5

\subsection{Spreadability}

The observations for spreadability of all formulations are shown in the table. The spreadability of the formulation depends on its viscosity. The greater the viscosity the longer will be the time taken for spreading on the skin.

\subsection{Determination of viscosity}

The measurement of viscosity of the prepared Emulgel was done with a Brookfield Viscometer was used to determine viscosity of the formulations. The viscosity was measured at $10 \mathrm{rpm}$ after 60 seconds. At each speed, the corresponding dial reading was noted. The viscosity of the emulgel was obtained. 


\subsection{Drug content determination}

Drug content was calculated using the following equation, which was obtained by linear regression analysis of calibration curve. The drug content of all emulgel formulation is found within range $97 \%-102 \%$.

Drug content $=($ concentration $\times$ dilution factor $\times$ volume taken $) \times$ conversion factor

\subsection{In vitro drug release studies}

The in vitro diffusion studies of all formulations (F1 to F6) were conducted and the results are shown in Table No.7, 8. The amount of drug released from different formulations F1, F2, F3, F4, F5 and F6 at the end of 8hrs were 42.12\%, $49.65 \%, 43.05 \%, 54.98 \%, 47.29 \%$ and $58.57 \%$ respectively.

\section{Conclusion}

Clotrimazole emulgel formulations were prepared by using polymers like Carbopol 934 and HPMC K4M showed acceptable physical properties, viscosity and drug release. HPMC K4M based emulgel in its High concentration i.e., F6 proved to be the optimized formulation, since it showed highest drug release i.e., $58.57 \%$ in $8 \mathrm{hrs}$. The release of Clotrimazole from the emulgel was observed as sustained release in a controlled manner. So, emulgel is one of the best topical drug deliveries and it is very effective for loading of hydrophobic drugs.

\section{Compliance with ethical standards}

\section{Acknowledgments}

The authors are extremely thankful to Narasaraopeta Institute of Pharmaceutical Sciences, Narasaraopeta, Andhra Pradesh, India for providing all the facilities to carry out this research work.

\section{Disclosure of conflict of interest}

The authors have declared that, there is no conflicts of interest exist in this research article.

\section{References}

[1] Lawrence H. Block.(2006). Medicated Topicals, Ch.44 in Remington. In: Lippincott Williams and Wilkins, editors. The science and practice of pharmacy 21th ed. Philadelphia.

[2] LLackman, HA, Lieberman and JL Kanig. Theory \& Practice of Industrial Pharmacy, Lea \& Fibiger, Philadelphia Latest Edn.

[3] Mohamed MI. (2004). Topical emulsion- gel composition comprising diclofenac sodium. AAPS Journal, 6(3).

[4] Mohamed MI. (2004) Optimization of Cholrphensinemulgel formulation. AAPS Journal, 6, (26).

[5] Rieger MM, Lachmann L, Lieberman HA andKanig JL. (1986). In: Lea and Fibiger, editors. the theory and the practice of industrial pharmacy 3rd ed. Philadelphia.

[6] Shahin M, Abdel Hady S, Hammad M andMortada N.(2010). Optimized formulation for topical administration of Clotrimazole using pemulen polymeric emulsifier: a conceptual framework. Drug development and industrial pharmacy, 37(5), 559-568.

[7] Steven P. Gelone. (2006) Anti- infectives, Ch. 90 in Remington. In: Lippincott Williams and Wilkins, editors. The science and practice of pharmacy 21 Th ed. Philadelphia: Lippincott Williams and Wilkins.

[8] The Merk Index In: MaryadeleJ.0, Neil, editor. (2006). An encyclopedia of Chemicals, Drugs and Biologicals 14 the d. NJ, USA: Merck and co.pg no 676-700

[9] Martindale. (2009). The complete drug references: Sean C Sweet man, editor. 36th Ed. The pharmaceutical press.

[10] Sunil KY, Manoj KM and Anupamaa T. (2017) AshutoshShukla. "Emulgel: a new approach for enhanced topical drug delivery." Int J CurrPharma Res, 9(1), 15-19.

[11] Date AA, Naik B and Nagarsenker MS. (2006) Novel Drug Delivery Systems: Potential in improving topical delivery of anti acne agents. Skin PharmacolPhysol, 19(1), 2-16. 
[12] Joshi M, Butola BS andSaha K. (2014) Advances in topical drug delivery system: micro to nanofibrous structures. J Menisci Nanotechnology, 14, 853-67.

[13] Tortora GJ and Anagnodokas. Principles of Anatomy and Physiology, N.P Happer\& Row Publishers N.Y.

[14] Ross \& Wilson, Anatomy and Physiology in the health and illness, third edition, pg no:236-301.

[15] AS Panwar, N Upadhyay, M Bairagi, S Gujar, GN Darwhekar and DK Jain.(2011). Emulgel: A Review. Asian J Pharmacy \& life Sci, 1(3), 333-343.

[16] Joshi Bhaibav et al. (2012). ClarithromycinEmulgel for topical delivery. International Journal of Drug Development \& Research, 4(3), ISSN0975-9344.

[17] Snehal P Mulye, et al. (2013). Formulation and Evaluation of Indomethacin Emulgel. Der Pharmacia Sinica, 4(5), 31-45.

[18] Joshi Bhaibav, et al. (2012). Clarithromycin Emulgel for topical delivery: International Journal of Drug Development \& Research, 4(3), ISSN 0975-9344.

[19] Monika Rao, et al. (2013). Optimization of Metronidazole Emulgel. Journal of Pharmaceutics, 501082.

[20] Dalia Abd El Rhman, et al. (2012). Formulation and evaluation of Fluconazole Emulge. International Journal of Pharmacy and Pharmaceutical sciences, 4(5), 176-183. 